\title{
Fertiliser characteristics of stored spent mushroom substrate as a sustainable source of nutrients and organic matter for tillage, grassland and agricultural soils
}

\author{
B. Velusami ${ }^{1,2}$, S.N. Jordan ${ }^{3}$, T. Curran ${ }^{2}$, H. Grogan ${ }^{1 \dagger}$
}

${ }^{1}$ Horticulture Development Department, Teagasc Research Centre, Ashtown, Dublin 15, Ireland

${ }^{2}$ School of Biosystems and Food Engineering, University College Dublin, Belfield, Dublin 4, Ireland

${ }^{3}$ Centre for Freshwater and Environmental Studies, Department of Agriculture, Food and Animal Health, Dundalk Institute of Technology,

Dublin Road, Dundalk, Co. Louth, Ireland

Abstract

Spent mushroom substrate (SMS) is an organic manure that can be used with advantage in agriculture. Under European Union (EU) (Good Agricultural Practice for Protection of Waters) Regulations, SMS cannot be applied to land over the winter months and must be stored on concrete surfaces, either covered or uncovered, to prevent nutrient-rich runoff seeping into groundwater. Spent mushroom substrate at four storage facilities, two covered and two uncovered, was analysed for physical and chemical characteristics after storage for up to 12 mo. Significant differences $(P<0.05)$ were identified for all parameters across the four sites, except for $\mathrm{pH}$, but there were no consistent differences that correlated with uncovered or covered storage conditions. The content of nitrogen $(\mathrm{N})$ and manganese (Mn) was significantly lower in uncovered SMS, while the content of iron ( $\mathrm{Fe})$ and copper (Cu) was significantly higher. The chemical nitrogen-phospous-potassium (NPK) fertiliser equivalent value of SMS, when applied at a rate of 10 t/ha, was between $€ 105$ and $€ 191$ per hectare. Nitrogen-phospous-potassium concentrations per kg wet weight were all higher in SMS that was stored under cover, meaning higher chemical fertiliser savings are possible. The high pH of stored SMS (7.8-8.1) means it could be used with good effect on acid soils instead of ground limestone. The low bulk density of SMS $\left(0.545-0.593 \mathrm{~g} / \mathrm{cm}^{3}\right)$ makes it an ideal amendment to soils to improve soil structure and quality. There is some variability in the nutrient content of SMS from different sources, so it is advisable to get the material analysed when including in nutrient management plans.

Keywords

Biofertiliser • circular economy • fertiliser value • organic matter $\bullet$ soil health

\section{Introduction}

The substrate used to grow the white button mushroom Agaricus bisporus (Lange) Imbach is a composted organic substrate produced from wheat or other cereal straw, animal manure such as poultry litter or horse manure, gypsum and sometimes additional nitrogen supplements (Noble \& Gaze, 1994; Beyer, 2003). It goes through a process of high-temperature composting, followed by pasteurisation, inoculation with a mushroom culture, incubation and finally mushroom production in a series of "flushes" over several weeks. When the substrate no longer produces commercially viable yields of mushrooms, usually after three flushes, it is considered as "spent mushroom substrate" (SMS) although it still contains considerable quantities of nutrients and can still produce further smaller flushes of mushrooms. Most commercial growers treat the SMS by steaming to eradicate pathogens before removal from the growing room while some remove it without steaming. Spent mushroom substrate from the mushroom industry has many potential applications in horticulture and agriculture such as an organic fertiliser providing supplemental nutrient sources for growing crops, as a soil conditioner for improving the chemical and physical properties of soil, as an ingredient in horticultural substrate mixes, for home gardening and other uses (Uzun, 2004; Fidanza et al., 2006; Ryu et al., 2008; Fidanza \& Davis, 2009; Phan \& Sabaratnam, 2012; Rinker, 2017). A recent European Union (EU)-funded project BIOrescue (2016-2019) has taken a technological approach to find uses for SMS with a "resource-efficient biorefinery concept" that would allow its transformation into valuable bio-based products, such as biopesticides, biodegradable nano-carriers for drug or fertiliser encapsulation and bio-based horticultural fertilisers (www. biorescue.eu). The quantity of $A$. bisporus-derived SMS 
produced annually by the mushroom industry around the world is approximately 9.6 million $(\mathrm{M})$ tonnes $(\mathrm{t})$, of which Europe accounts for $3.6 \mathrm{M} \mathrm{t}$, North America, $1.5 \mathrm{M} \mathrm{t}$ and China, $4 \mathrm{M} \mathrm{t}$ (B. Burns, Sylvan, personal communication). In Ireland, about 180,000 t of SMS is generated per year (D. Gernon, Teagasc, personal communication).

The recent EU Fertiliser Regulation 2019/1009 promotes the use of recycled nutrients in the circular economy, highlighting the need to make use of recycled or organic materials for fertilising purposes. This would allow a more resource-efficient general use of nutrients, while reducing EU dependency on nutrients from third countries (Anon, 2019). Spent mushroom substrate as a fertiliser is a good source of nitrogen $(\mathrm{N})$, phosphorus $(P)$, potassium $(K)$ as well as other minerals (calcium $(\mathrm{Ca})$, magnesium $(\mathrm{Mg})$, iron $(\mathrm{Fe})$, manganese $(\mathrm{Mn})$, zinc $(\mathrm{Zn})$ and copper (Cu)); however, it does not contain sufficient $\mathrm{N}$ to provide the total $\mathrm{N}$ requirement for optimum plant growth (Stewart et al., 1998; Uzun, 2004; Walsh, 2013) and, furthermore, only a proportion of the total $\mathrm{N}$ is available for uptake by plants in the year of use (Hackett, 2015). The main advantages of SMS as a fertiliser are the slow release of nutrients, an increase in soil organic matter and the improvement of soil structure and health, attributes which are visible in the years following the initial application (Curtin \& Mullen, 2007; Gümüs \& Seker, 2017). Agricultural sustainability requires good soil management and the preservation of soil organic matter, and one way of achieving this is to recycle organic products, such as SMS, by incorporation into agricultural land (White et al., 2014). The relatively low bulk density, high organic matter and moisture content of SMS enhance crop growth (Stewart et al., 1998), but its high salt content can inhibit plant growth at high application rates (Abrol et al., 1988). Salt content will decrease during storage, especially if SMS is exposed to rainfall, due to leaching of $\mathrm{K}, \mathrm{Mg}$, sodium ( $\mathrm{Na}$ ), $\mathrm{Ca}, \mathrm{Cl}$, sulphate and nitrate ions (Uzun, 2004). The main disadvantage of SMS compared to chemical fertilisers is the need to store and transport it. Sufficient land is not usually available in the vicinity of mushroom production units to spread the entire quantity of SMS generated, so it is necessary for it to be transported to other areas, or utilised for horticultural or other purposes (Westerman \& Bicudo, 2005).

Storage and use of SMS in Ireland are regulated in accordance with the Statutory Instrument (S.I.) No 605 of 2017 of the European Union (Good Agricultural Practice for Protection of Waters) Regulations 2017 (Anon, 2017). This regulates the rate of use of SMS based on its available $\mathrm{N}$ and $\mathrm{P}$ values to prevent contamination of surface or ground water. According to S.I. No. 605 of 2017, SMS contains $8 \mathrm{~kg} / \mathrm{t}$ of total $\mathrm{N}$ and $1.5 \mathrm{~kg} / \mathrm{t}$ of total $\mathrm{P}$ (fresh weight basis), with $20 \%$ of the $\mathrm{N}$ and $100 \%$ of the $P$ being available for crop growth (Anon, 2017), so more attention must now be given to nutrient content and application rates. Currently, all SMS must be stored on concrete, and any leachate must be collected in order to prevent undesired pollution (Anon, 2017). Application of SMS to land is also prohibited in the winter between $15^{\text {th }}$ October and $1^{\text {st }}$ February, when rainfall levels are high, to protect surface and ground waters from pollution. During storage, the SMS will continue to undergo further decomposition, which will vary depending on whether it is stored outdoors or under cover, or in large or small heaps. This may affect the nutrient content of the material when used as a fertiliser. The aim of this study was to characterise and compare the physical and chemical properties of SMS stored at different sites either outdoor or under cover and to assess any impact of storage conditions on the nutrient value of SMS as a fertiliser with respect to all major macro and micro nutrients.

\section{Materials and methods}

\section{SMS Storage sites}

Four SMS storage sites around Ireland were visited between February 2008 and October 2009. Two were uncovered outdoor sites (site 1 in the east and site 2 in the north west) with retaining concrete side walls to $2.5 \mathrm{~m}$. Average monthly rainfall at site 1 was $65-97 \mathrm{~mm}$ and at site 2 it was 108-116 $\mathrm{mm}$ (Velusami et al., 2013). Two sites were covered (site 3 in the east and site 4 in the south), which had retaining concrete side walls to $2.5 \mathrm{~m}$ and an apex roof structure mounted on steel supports to produce an open-sided barn construction above the retaining walls. The site conditions are described in Velusami et al. (2013). Sites 1, 2 and 3 consisted of relatively large heaps $\left(1450-5000 \mathrm{~m}^{3}\right.$ ), while site 4 was smaller (about $600 \mathrm{~m}^{3}$ ) (Figure 1).

\section{Sample collection}

Spent mushroom substrate samples were collected on days in 2008 and 2009 when the stored SMS was being removed for land application or was being turned to facilitate degradation as described in in the study by Velusami et al. (2013). Approximately $3-5 \mathrm{~kg}$ of SMS was taken from the top, middle and bottom of the SMS heaps at intervals across the full length and width of the heaps and mixed well prior to sub-sampling. The age of SMS within the heaps varied from fresh to up to 12 mo old. In total, 354 samples of SMS were collected, out of which 150 were from outdoor sites and 204 were from covered sites, with at least 75 samples from each site.

\section{Personal safety}

A Cen-Paq personal breathing apparatus with bottled air and full face mask (Keison Products, Chelmsford, UK) was worn by research personnel during the first visits to sites 1 and 2 in 2008 due to the risk of exposure to toxic $\mathrm{H}_{2} \mathrm{~S}$ gas when the stored SMS was being removed (Velusami et al., 2013). It was subsequently decided that adequate protection from $\mathrm{H}_{2} \mathrm{~S}$ 

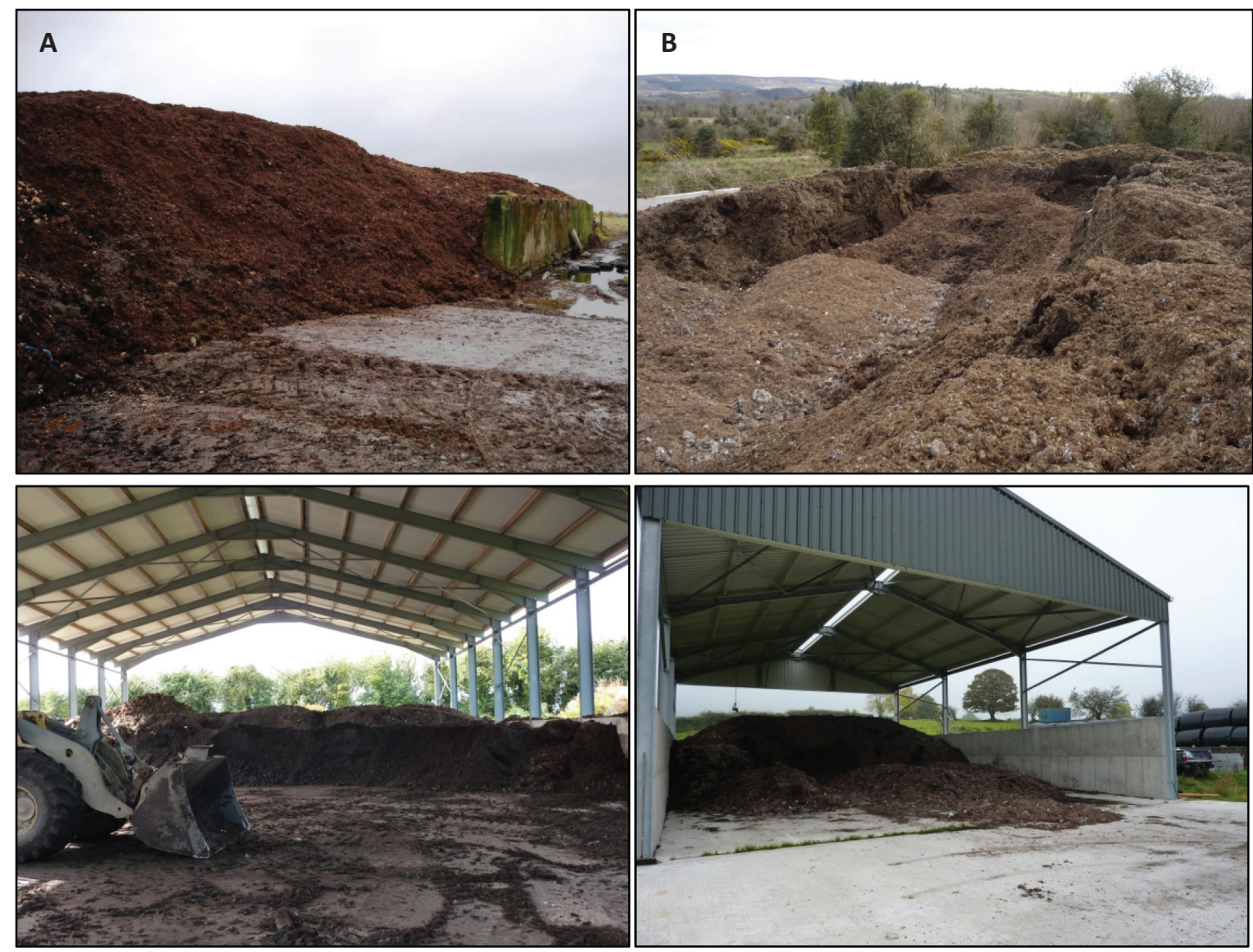

Figure 1. SMS storage sites: Outdoor uncovered sites: (A) site 1; (B) site 2; covered sites: (C) site 3 and (D) site 4.

exposure could be obtained by wearing a full face mask for respiratory protection (EN 136:1998 CL 1) fitted with $\mathrm{H}_{2} \mathrm{~S}$ filter (code EN 141 A1B1E1K1), available from suppliers of health and safety equipment, and these were used on all subsequent visits. Disposable Tyvek (Uvex Arbeitsschutz GMBH, Fürth, Germany) suits and QRAE+/QRAE II $\mathrm{H}_{2} \mathrm{~S}$ monitors (Rae Systems, San Jose, USA) (supplied and serviced by Seridan Safety, Dublin, Ireland, www.seridan.com) were worn by research personnel during all operations.

\section{Physical property analysis}

Temperature: A Eurolec TH103 thermocouple (Eurolec Instrumentation Ltd., Louth, Ireland, www.eurolec-instruments. com) of $1.5 \mathrm{~m}$ length was used to measure the temperature of the SMS at various locations across the length, width and depth of the SMS heap during removal. Measurements were taken at approximately $50 \mathrm{~cm}$ from the top and bottom surfaces of the heaps as well as in the middle, as described in the study by Velusami et al. (2013).

Moisture content: For each SMS sample taken, $2 \times 150 \mathrm{~g}$ subsamples were oven-dried at $105^{\circ} \mathrm{C}$ for $24 \mathrm{~h}$. The moisture content (\%) of each SMS sample was calculated by gravimetric difference of fresh and dried weight, as described in the study by Velusami et al. (2013).

Milling: An MF10 Basic microfine grinder (IKA ${ }^{\circledR}$-Werke $\mathrm{GmbH}$ \& Co. KG, Staufen Germany) was used to mill the dried SMS samples to obtain ground particles that passed through a 0.25 -mm sieve.

Ash content: $2.5 \mathrm{~g}$ of dried and milled SMS samples (two replicates) were weighed in crucibles and placed in a Carbolite laboratory muffle furnace (Carbolite Gero Ltd. Hope, UK) for $24 \mathrm{~h}$ at $500^{\circ} \mathrm{C}$. Percentage ash content was calculated by gravimetric difference.

Bulk density: The bulk density was calculated by gravimetric difference according to the method of Noble et al. (1999) and following Irish Standard EN 13041:2011 (CEN, 2011). Wet SMS samples were filtered through a $20-\mathrm{mm}$ sieve and filled into a 1-L bulk density-measuring cylinder with extension collar, which was then gently tapped and shaken. A standard weight $(650 \mathrm{~g}$ ) was placed on top of the sample for $3 \mathrm{~min}$, after which the weight and collar were removed and the sample was levelled flush with the top of the test cylinder. After levelling, the remaining contents were weighed and the bulk density was calculated as $\mathrm{g} / \mathrm{L}$. The process was repeated for each sample. 
Electrical conductivity and $\mathrm{pH}: 40 \mathrm{~g}$ SMS samples (two replicates) were mixed with $400 \mathrm{~mL}$ of deionised water and shaken for $1 \mathrm{~h}$ at $450 \mathrm{rpm}$. After shaking, the samples were left to settle suspended particles and the $\mathrm{pH}$ and conductivity were measured using a Eutech PC 700 (Eutech Instruments Europe B.V., Nijkerk, Netherlands).

\section{Mineral analysis}

Total N, C, H and S content: Total N, carbon (C), hydrogen $(\mathrm{H})$ and sulphur (S) were determined by the Dumas method using an Elementar vario MACRO cube (Elementar Analysensysteme $\mathrm{GmbH}$, Langenselbold, Germany) (https:// www.elementar.com/en/products/organic-elementalanalyzers/vario-macro-cube). Each sample consisted of 5 $\mathrm{mg}$ of dried and milled SMS (two replicates). Samples were combusted at $1150^{\circ} \mathrm{C}$ in the presence of oxygen which leads to the reduction of combustion gases $\left(\mathrm{N}_{2}, \mathrm{CO}_{2}, \mathrm{H}_{2} \mathrm{O}\right.$ and $\left.\mathrm{SO}_{2}\right)$. These gas mixtures are separated in specific columns and fed into a thermal conductivity detector for quantification based on stored calibration curves.

Total Cu, Fe, Pb, Mn, Mg, Ca, Na, K, P and B content: A 0.1-g quantity of each dried and milled sample of SMS was digested in acid using a MARS microwave digestion system (CEM Microwave Technology (Ireland) Ltd., Dublin, Ireland). The acid-digested solution was diluted appropriately and analysed for $\mathrm{Cu}$, Fe, lead (Pb), Mn, Mg, Ca, Na, K and boron (B). They were determined by atomic absorption spectrophotometry (AAS) (Varian, 1989) using an air and/or nitrous oxide-acetylene flame. The appropriate standard curves were prepared using commercially available atomic absorption standards. The aciddigested $P$ filtrates were diluted appropriately and analysed calorimetrically for total $\mathrm{P}$ by ultraviolet spectrophotometer (Jenway UV/Vis Spectrophotometer 7305, Stone, UK) at 712 nm (Rowell, 1994).

\section{Statistical analysis}

The physical and chemical data were initially analysed to give the mean, minimum and maximum values for each parameter analysed, along with the standard deviation and coefficient of variation. The data were further analysed by one-way independent analysis of variance (ANOVA) and tested for significant differences using Duncan's post-hoc test using the 'Statistical Package for the Social Sciences' (SPSS) version 20 (IBM, 2011).

\section{Results}

Significant differences were identified for most of the physical and chemical characteristics of SMS stored at the four different sites, but for most of the chemical parameters there were no consistent differences that correlated with uncovered or covered storage conditions, highlighting the somewhat variable nature of the material from site to site. The content of $\mathrm{N}$ and $\mathrm{Mn}$ was significantly lower in uncovered outdoor-stored SMS while the content of $\mathrm{Fe}$ and $\mathrm{Cu}$ was significantly higher (Figure 2).

\section{Physical properties of SMS}

The mean temperature of SMS stored at outdoor uncovered sites 1 and 2 at the time of sampling was significantly lower $(P<0.05)$ at $29^{\circ} \mathrm{C}$ compared to $37-42^{\circ} \mathrm{C}$ for SMS stored undercover at sites 3 and 4 (Table 1). Moisture content was significantly higher for the outdoor-stored SMS at 69-70\% compared to $59-64 \%$ for indoor-stored SMS. The mean bulk density of SMS was also significantly higher at outdoor sites 1 and 2 at $0.57-0.59 \mathrm{~g} / \mathrm{cm}^{3}$ compared to SMS at the covered site 4 at $0.55 \mathrm{~g} / \mathrm{cm}^{3}$, but the bulk density at site 3 was intermediary at $0.56 \mathrm{~g} / \mathrm{cm}^{3}$ (Table 1). There was no significant difference in the mean $\mathrm{pH}$ of stored SMS across all sites (7.8-8.1). There was no significant difference in the mean electrical conductivity of stored SMS at sites 1,2 and 3 , with values of $2.53-2.80 \mathrm{mS} / \mathrm{cm}$; however, the conductivity of SMS from site 4 was significantly higher than that for other sites at $3.51 \mathrm{mS} / \mathrm{cm}$. Ash content was significantly different across all sites, ranging from 34 to $39 \%$ but was highest at site 4 (Table 1).

\section{Mineral content of SMS}

Figure 2 shows the mean content of non-metal minerals (Figure 2A), alkali and alkaline metals (Figure 2B) and B plus other metals (Figure $2 \mathrm{C}$ ) in stored SMS at two uncovered and two covered SMS storage sites. Additional data (minimum and maximum values, s.d. and CV) are available in Supplementary Table S1. Although there were significant differences in the mineral content of SMS across the four sites, there was no consistent pattern that reflected storage in the open or storage under cover.

Concerning the key minerals of importance for agriculture $(\mathrm{N}, \mathrm{P}, \mathrm{K}, \mathrm{Ca}, \mathrm{Mg}$ and $\mathrm{S})$, there were significant differences in mineral content of SMS from the different sites (Figure 2A, 2B). Mean total $\mathrm{N}$ of SMS stored undercover was significantly higher $(P<0.5)$ than outdoor-stored SMS. The mean total $P$ of stored SMS varied significantly from site to site but did not reflect storage type. Mean total K of stored SMS was variable across the sites with the maximum value recorded for SMS stored undercover at site 4 and the minimum value recorded for the outdoor-stored SMS at site 2. The average concentration of $\mathrm{Ca}$ was also variable across the sites with SMS at site 2 having more than double the $\mathrm{Ca}$ content compared to other sites, but there was considerable variation in Ca across all sites (Table S1). Magnesium concentrations were very similar across all four sites while there was more variability in $\mathrm{S}$ concentrations across the sites. Carbon was the most abundant element, accounting for $319-336 \mathrm{~g} / \mathrm{kg}$, almost a third of the dry weight. 

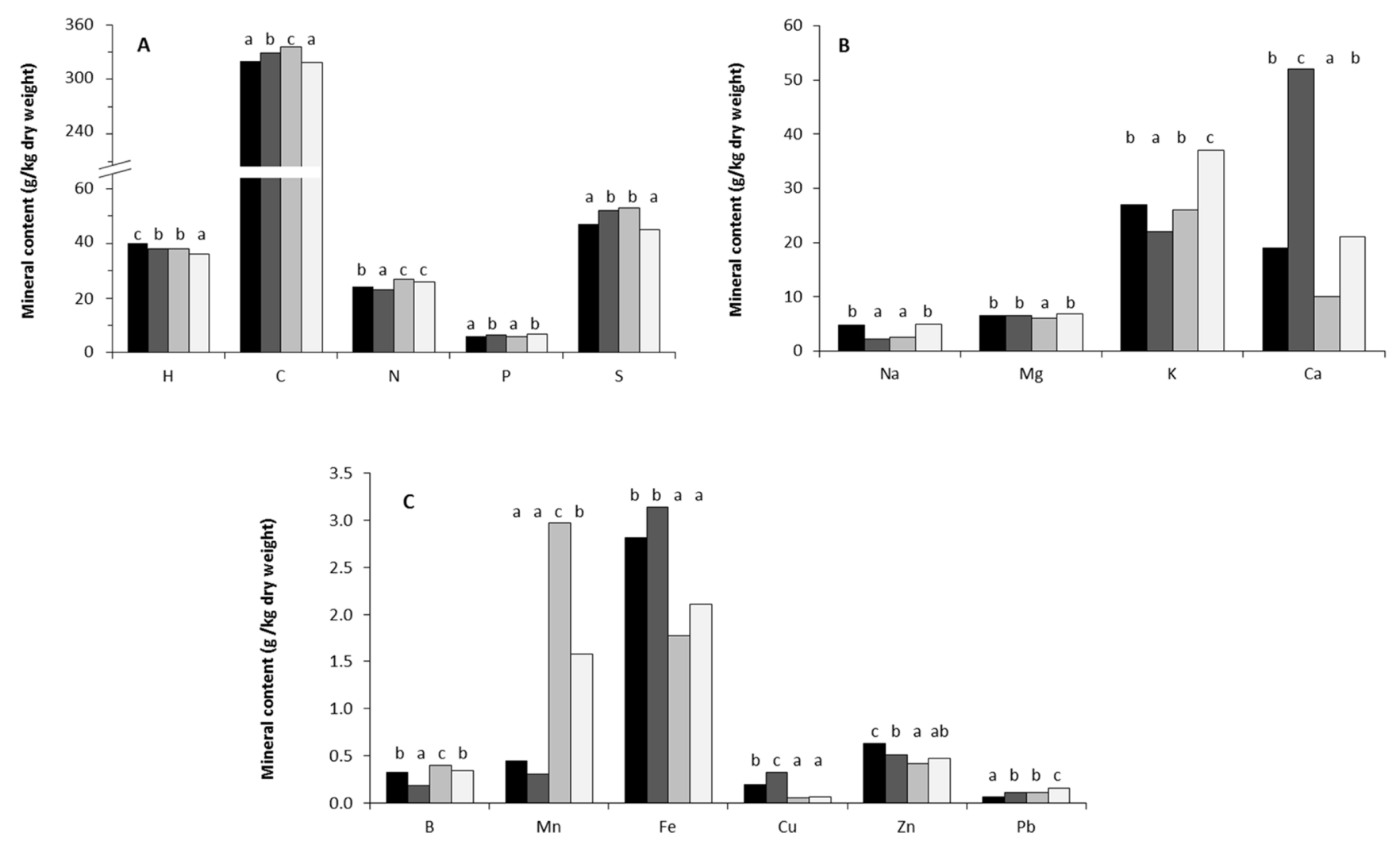

Figure 2. Mineral content of SMS taken from four storage sites: (A) non-metals; (B) alkali and alkaline metals, and (C) boron and other metals. $\square=$ outdoor site 1 ; $\square=$ outdoor site 2 ; $\square=$ covered site 3 and $\square=$ covered site 4 . For each mineral, site means sharing a common letter are not significantly different at $P<0.05$.

Table 1: Physical properties of SMS stored at four sites for up to 12 mo in 2008 and 2009 and sampled when SMS was being applied to land (sites 1, 3 and 4 ) or being turned (site 2)

\begin{tabular}{|c|c|c|c|c|c|c|c|c|}
\hline Site & $\mathrm{N}(\mathrm{nT})^{1}$ & Storage type & Temperature $^{1}$ & Moisture $^{1}$ & Bulk density & $\mathrm{pH}$ & EC & Ash \\
\hline & & & $\left({ }^{\circ} \mathrm{C}\right)$ & $(\%)^{2}$ & $\left(\mathrm{~g} / \mathrm{cm}^{3}\right)^{2}$ & & $(\mathrm{mS} / \mathrm{cm})$ & $(\%)^{3}$ \\
\hline Site 1 & $93(194)$ & Uncovered & $29^{a}(6.3)^{4}$ & $69^{\circ}(2.4)$ & $0.568^{b}(48)$ & $7.9^{\mathrm{a}}(1.1)$ & $2.7^{\mathrm{a}}(0.7)$ & $34^{a}(2.8)$ \\
\hline Site 2 & 57 (111) & Uncovered & $29^{\mathrm{a}}(7.2)$ & $70^{c}(1.8)$ & $0.593^{\mathrm{c}}(91)$ & $7.8^{\mathrm{a}}(0.7)$ & $2.5^{\mathrm{a}}(0.5)$ & $37^{\circ}(3.7)$ \\
\hline Site 3 & $144(85)$ & Covered & $42^{c}(10.0)$ & $64^{\mathrm{b}}(4.3)$ & $0.556^{\mathrm{ab}}(41)$ & $8.1^{\mathrm{a}}(0.8)$ & $2.8^{\mathrm{a}}(0.8)$ & $35^{b}(2.2)$ \\
\hline Site 4 & $60(75)$ & Covered & $37^{b}(4.6)$ & $59^{a}(9.3)$ & $0.545^{\mathrm{a}}(95)$ & $7.9^{\mathrm{a}}(0.9)$ & $3.5^{\mathrm{b}}(1.5)$ & $39^{d}(2.3)$ \\
\hline
\end{tabular}

${ }^{1} \mathrm{~N}=$ number of samples; $(\mathrm{nT})=$ number of samples for temperature measurements. Data are means (s.d. in brackets); Temperature and moisture data are based on an expanded data set from what is presented in Velusami et al. (2013), and which is presented here as the overall mean for each site.

${ }^{2}$ Calculated on a fresh weight basis.

${ }^{3}$ Calculated on a dry weight basis.

${ }^{4}$ Means within columns followed by the same letter are not significantly different $(P<0.05)$.

Concentrations of the trace elements $\mathrm{Fe}$ and $\mathrm{Cu}$ were significantly higher $(P<0.05)$ in SMS stored uncovered compared to that stored under cover, while Mn concentrations were significantly lower $(P<0.05)$ in SMS stored uncovered. Concentrations of $\mathrm{B}$ and $\mathrm{Zn}$, important trace elements, were variable across the sites (Figure $2 \mathrm{C}$ ).

\section{Fertiliser value of SMS for agriculture}

The N, P and $\mathrm{K}$ contents in Figure 2 were converted to the equivalent values on a wet weight basis (Table 2) as it is this value that is used in nutrient management plans when applying SMS as a fertiliser to soil. The availability of each nutrient to the crop in the year of application is given along 


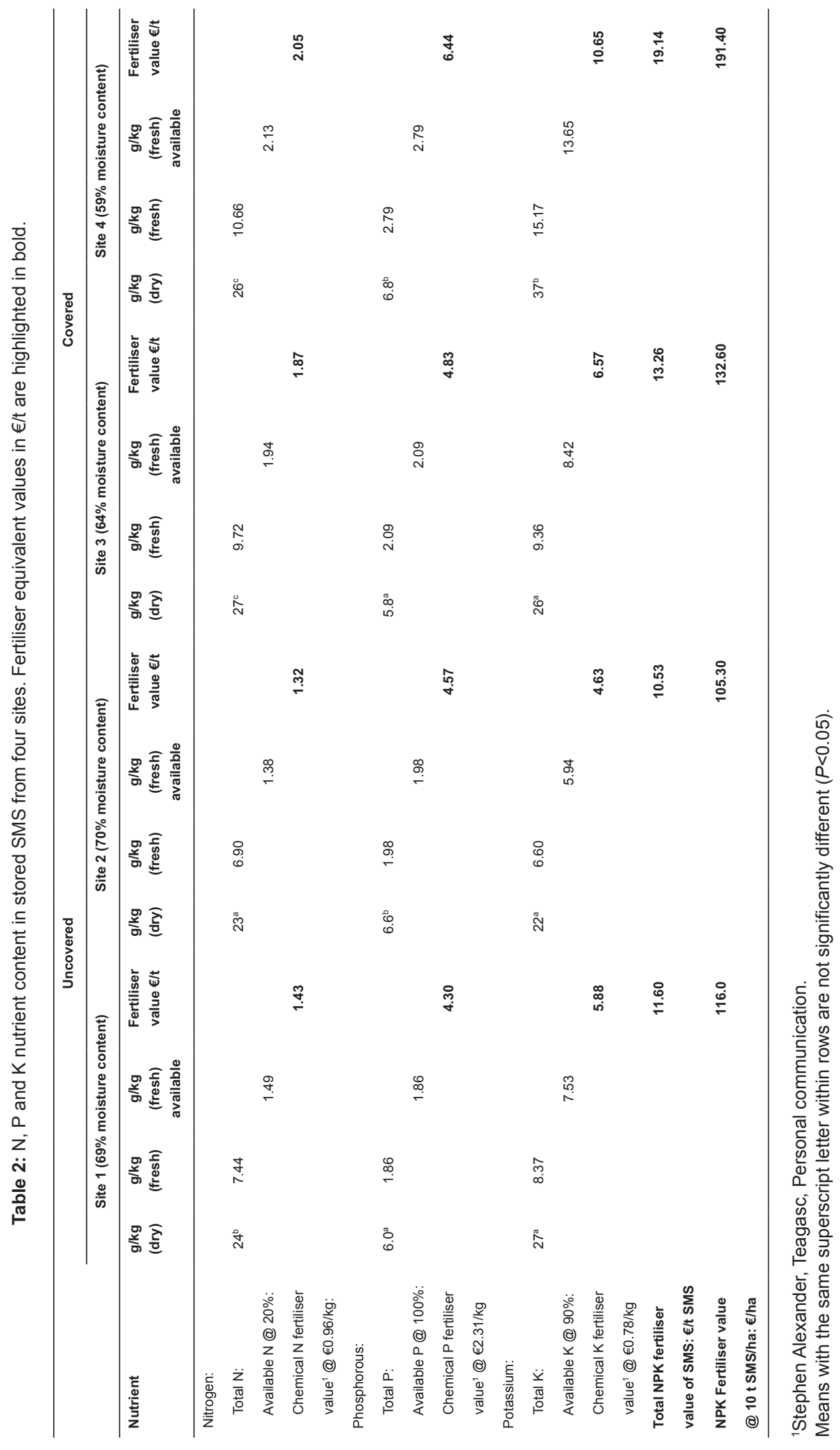


with the monetary value of the nutrient content in terms of the equivalent cost of a chemical fertiliser. All were present at higher concentrations per $\mathrm{kg}$ wet weight in SMS that was stored under cover. The fertiliser equivalent value of NPK in SMS when applied at an average rate of 10 t/ha ranged between $€ 105$ and $€ 191$ per hectare. Average $\mathrm{Ca}, \mathrm{Mg}$ and $\mathrm{S}$ content in stored SMS was 5.9, 2.0 and $14.6 \mathrm{~g} / \mathrm{kg}$ (wet weight basis), respectively. The availability of $\mathrm{Ca}, \mathrm{Mg}$ and $\mathrm{S}$ in SMS to crops is not currently known.

\section{Discussion}

Spent mushroom substrate is a valuable fertiliser for agriculture containing the key nutrients $\mathrm{N}, \mathrm{P}$ and $\mathrm{K}$ and, when applied at an average rate of $10 \mathrm{t} / \mathrm{ha}$, has an economic value of between $€ 105$ and $€ 191$ per hectare (Table 2). Characteristics of SMS can vary slightly, albeit significantly, between different sources for different reasons, such as the initial raw ingredients, whether or not the SMS is fresh or stored, whether it is stored in the open or under cover and what the prevailing weather conditions are at the storage location (Figure 2, Table S1), and this can affect the NPK content and subsequent fertiliser value. According to S.I. No. 605 of 2017, SMS is assumed to contain $8 \mathrm{~g} / \mathrm{kg}$ (wet weight) of total $\mathrm{N}$ with $20 \%$ of the $\mathrm{N}(1.6 \mathrm{~g} / \mathrm{kg})$ available for crop growth (Anon, 2017). This is not sufficient for the total needs of most crops, so additional inorganic $\mathrm{N}$ will be required (Stewart et al., 1998; Hackett, 2015). The mean total $\mathrm{N}$ of stored SMS in this study ranged between 23 and $27 \mathrm{~g} / \mathrm{kg}$ dry weight (6.9-10.7 $\mathrm{g} / \mathrm{kg}$ wet weight). These levels are similar to average total $\mathrm{N}$ contents reported for fresh SMS at $27 \mathrm{~g} / \mathrm{kg}$ and $21 \mathrm{~g} / \mathrm{kg}$ (dry weight) by Fidanza et al. (2010) and Jordan et al. (2008), respectively. The results showed that $\mathrm{N}$ levels were significantly higher on a dry weight basis, when SMS was stored under cover (Figure 2, Table S1). This may reflect loss of soluble $\mathrm{N}$ due to leaching from the uncovered SMS, which were exposed to significant rainfall during the storage period and had higher moisture contents. The difference was further emphasised when $\mathrm{N}$ content was converted to a wet weight basis, due to the fact that the SMS stored under cover was drier (Table 1 ) with a proportionately higher dry matter content. Farmers wishing to use SMS in their fertiliser regimes should take SMS storage conditions into consideration when preparing their nutrient management plans and assess the $\mathrm{N}$ content of SMS before spreading on the land as they may be able to reduce the amount of additional inorganic $\mathrm{N}$ needed (Table 2).

According to S.I. No. 605 of 2017, SMS in Ireland contains $1.5 \mathrm{~g} / \mathrm{kg}$ (wet weight) of total $\mathrm{P}$ with $50 \%$ and $100 \%$ of the $P$ available for crop growth on soils with Morgan's $P$ Index of 1 and 2, and on soils with a P Index of 3 and 4, respectively (Anon, 2017; Teagasc, 2017). According to Walsh (2009), SMS with a P content of $2.5 \mathrm{~kg} / \mathrm{t}$ (wet weight) applied at a rate of $9 \mathrm{t} / \mathrm{ha}$ can provide $22.5 \mathrm{~kg} / \mathrm{ha}$ $\mathrm{P}$ of the $25 \mathrm{~kg} / \mathrm{ha} \mathrm{P}$ requirement of a winter wheat crop on a tillage farm with a soil $P$ index of 3 , almost $100 \%$ of the crop requirement. The $\mathrm{P}$ content in SMS, the $\mathrm{P}$ index of the soil and the $P$ requirement of the crop will determine the maximum amount of SMS that can be applied to a particular soil as part of a fertilisation regime as $\mathrm{P}$ inputs to soil have to be monitored closely to prevent excessive $\mathrm{P}$ application and P contamination of ground water (Regan et al., 2012). The mean total P of stored SMS in this study (sampled in 2008 and 2009) ranged between 5.8 and $6.8 \mathrm{~g} / \mathrm{kg}$ (dry weight) with no clear correlation to storage conditions (Figure 2, Table S1). However, when $\mathrm{P}$ contents were converted to a wet weight basis (1.9-2.8 g/kg wet weight) (Table 2), the levels were higher in SMS stored under cover due to the fact that it was drier and with a proportionately higher dry matter content (Table 1). The levels were also higher than the $1.5 \mathrm{~kg} / \mathrm{t} \mathrm{P}$ content indicated in S.I. No. 605 of 2017, meaning that excessive $\mathrm{P}$ application could result, especially with the drier material. Walsh (2013) showed how P levels in fresh SMS were reducing over time, from $2.5 \mathrm{~kg} / \mathrm{t}$ in 2003 to $1.5 \mathrm{~kg} / \mathrm{t}$ in 2012, due to changes in composting techniques and higher crop yields, and the 2012 figure of $1.5 \mathrm{~kg} / \mathrm{t} \mathrm{P}$ value is what is currently used in S.I. No. 605 of 2017 (Anon, 2017). The SMS results presented in this paper were for samples taken in 2008 and 2009 and therefore do not fully reflect the changes highlighted by Walsh (2013). Phosphorus content at sites 1,2 and 3 were intermediary between Walsh's 2003 and 2012 figures at $1.9-2.1 \mathrm{~g} / \mathrm{kg}$ wet weight, but $P$ content at site 4 was higher at $2.8 \mathrm{~g} / \mathrm{kg}$. This site had the lowest moisture content at $59 \%$ compared to $64-70 \%$ for sites 1,2 and 3 , which increases nutrient content when converted from a dry weight to a fresh weight basis. Nonetheless, the variability in $P$ levels in SMS that has been demonstrated over the years suggests that they should be monitored on an ongoing basis to ensure that over application of $\mathrm{P}$ to soils in SMS is avoided. Potassium is an important element in crop nutrition and according to Walsh (2009), the K in SMS is $90 \%$ available and can supply $100 \%$ of the $\mathrm{K}$ requirement of a winter wheat crop on a soil with a $\mathrm{K}$ index of 3 . The mean total $\mathrm{K}$ of stored SMS in this study ranged between 22 and $37 \mathrm{~g} / \mathrm{kg}$ dry weight $(6.6-15 \mathrm{~g} / \mathrm{kg}$ wet weight) (Figure 2, Table S1), which is more variable compared to the $20 \mathrm{~g} / \mathrm{kg}$ and $24 \mathrm{~g} / \mathrm{kg}$ (dry weight) reported for fresh SMS by Jordan et al. (2008) and Fidanza et al. (2010), respectively. Walsh (2013) reported that fresh SMS contained between 9.7 and $5.4 \mathrm{~kg} / \mathrm{t} \mathrm{K}$ (wet weight) with high variability within samples. There was also high variability in the K content of SMS in all SMS samples (Table S1), but the content was higher and less variable in the drier SMS at sites 4 and 5 . This makes SMS, especially the drier material, a useful source of supplementary $\mathrm{K}$ worth in the region of $€ 5$ $10 / t$ (or $€ 50-100$ per hectare when applied at a rate of $10 \mathrm{t} / \mathrm{ha}$ ), contributing to overall soil fertility (Table 2). 
Calcium, $\mathrm{Mg}$ and $\mathrm{S}$, and the trace elements $\mathrm{Mn}$ and $\mathrm{B}$, are important elements and microelements for crop growth (Wall \& Plunkett, 2016) and are present in significant amounts in SMS. There was no clear relationship between nutrient content and storage conditions for $\mathrm{Ca}, \mathrm{Mg}, \mathrm{S}$ or $\mathrm{B}$ but $\mathrm{Mn}$ levels were significantly higher in the drier, indoor-stored SMS at sites 3 and 4 . Compared with $\mathrm{N}$ and $\mathrm{P}$, there was considerable variability recorded in the levels of these minerals in all SMS samples (Table S1), making SMS a useful supplementary source of these elements.

In addition to its fertiliser value, SMS is an important source of organic matter, which improves soil organic $\mathrm{C}$ and bulk density. As an organic manure, its application to sandy soils and soils under long-term tillage can help to improve soil structure and reduce soil erosion and nutrient loss (Hackett et al., 2010; Spink et al., 2010; Regan et al., 2012; Hackett, 2015; Gümüs \& Seker, 2017). Temperature and moisture content have a significant effect on microbial activity and the enzymatic degradation of SMS during storage, and organic substrates will continue to compost and break down over time (Liang et al., 2003). The moisture content was lower for SMS stored under cover compared to that stored outdoors, reflecting the fact that outdoor-stored material will capture more rainfall over time, particularly in areas of high rainfall, while the mean temperature of SMS stored under cover was consistently higher than outdoor-stored material (Table 1). Lower moisture content and higher temperatures during storage had the effect of reducing the bulk density of SMS stored under cover slightly but significantly (Table 1). The mean bulk density for the stored SMS during this study was $545-593 \mathrm{~kg} / \mathrm{m}^{3}$, with the drier SMS stored under cover having lower values. Soils with a high bulk density are more compacted, less productive and more prone to erosion and nutrient loss in runoff, so the inclusion of a low bulk density organic fertiliser like SMS is a good management tool to ameliorate heavily cultivated soils (Regan et al., 2012).

The optimum soil $\mathrm{pH}$ required for most agriculture and horticulture crops is in the range of 6.3-7.0 (Wall \& Plunkett, 2016). The mean $\mathrm{pH}$ of stored SMS in this study was $7.8-8.1$ (Table 1), while the average $\mathrm{pH}$ for fresh SMS is 6.6-6.8 (Jordan et al., 2008; Fidanza et al., 2010). The application of SMS to a fine sandy loam soil with $\mathrm{pH} 6.5$ resulted in an increase in soil pH over a 4-year period (Stewart et al., 1998) but had no effect on an alkaline clayey-loam soil (Medina et al., 2012); thus, consideration should be given to the $\mathrm{pH}$ of the soil when applying SMS and it could be used with benefit on acidic soils, replacing or supplementing applications of ground limestone.

Soil salinity affects plant growth, with increasing salinity causing restricted growth and plant death (Abrol et al., 1988), and with some plants being more sensitive than others (Medina et al., 2009). Non-saline soils have an EC value of $0-2 \mathrm{dS} / \mathrm{m}$
(=0-2 $\mathrm{mS} / \mathrm{cm}$ ) while soils of $2-4 \mathrm{dS} / \mathrm{m}$ are considered slightly saline, and effects on the growth of sensitive crop plants may be restricted. The mean electrical conductivity of stored SMS in this study was $2.53-3.51 \mathrm{mS} / \mathrm{cm}$ (Table 1), which was lower than the $13.3 \mathrm{mS} / \mathrm{cm}$ reported by Fidanza et al. (2010) to be not high enough to damage turf grass, and the $10.0 \mathrm{mS} / \mathrm{cm}$ reported for fresh SMS by Jordan et al. (2008). Fresh SMS, with higher EC values, can have greater detrimental effects on the growth of some plants compared with stored SMS; therefore, it should be applied with care. The EC for SMS following a 56-day in-vessel composting process without turning was intermediate between these two at $6.2 \mathrm{mS} / \mathrm{cm}$ (Fleming \& MacAlpine, 2006), which could also have implications for plant growth. Water-soluble ions can leach out from SMS during storage, especially when stored at outdoor locations, where it can be exposed to rainwater and snow. The EC of SMS stored undercover at site 4 was significantly higher than that stored outdoors, at $3.51 \mathrm{mS} / \mathrm{cm}$, and was more variable than those for all other sites (Table S1) although leaching during storage under cover can still occur, as rainfall can enter via the open sides of the structures. Thus, storage conditions, rainfall and local weather will have an impact on the characteristics of SMS; this highlights the need to have SMS analysed prior to use to identify potential EC characteristics that could influence decision-making on its rate of use.

\section{Conclusion}

Spent mushroom substrate is a regularly available organic manure which is often stored until needed. The economic value of SMS as a source of NPK and other elements for agricultural crop production is significant with a chemical fertiliser equivalent value of between $€ 105$ and $€ 191$ per hectare, when applied at an average rate of $10 \mathrm{t} / \mathrm{ha}$. Spent mushroom substrate stored undercover is drier and has higher NPK contents on a fresh weight basis, thereby increasing its value as a biofertiliser. The use of SMS as a "biofertiliser" is a way of ensuring greater resource efficiency in a circular economy and would reduce the requirement for chemical fertilisers that can be more labile and polluting. The high $\mathrm{pH}$ of stored SMS means it could be used with good effect on acid soils instead of ground limestone, again saving on cost. The low bulk density of SMS makes it an ideal amendment to heavily tilled and compacted soils where it will improve soil health, structure and quality, thereby reducing the risk of soil and nutrient erosion, which can lead to surface and ground water contamination. There is some variability in the nutrient content of SMS from different sources, so it is advisable to get SMS analysed on a regular basis. Farmers need to be aware of this variability so that they can include the most relevant information in their nutrient management plans. 


\section{Acknowledgements}

The authors acknowledge funding from the Teagasc Walsh Scholarship Programme for Balasubramanian Velusami. This paper is based on Chapter 6 of his PhD thesis (Velusami, 2013). The assistance of Brian McGuinness with fieldwork and Miguel Prieto with manuscript preparation is acknowledged.

\section{References}

Abrol, I.P., Yadav, J.S.P. and Massoud, F.I. 1988. Saline soils and their management. In: "Salt-Affected Soils and their Management". FAO Soils Bulletin 39. Available online: http://www.fao.org/3/x5871e/ x5871e04.htm\#3 [Accessed 24 September 2019], 30 pages.

Anon. 2017. European Union (Good Agricultural Practice for Protection of Waters) Regulations 2017. SI 605 of 2017. Available online: https://www.agriculture.gov.ie/media/migration/ruralenvironment/ environment/nitrates/2017/SINo605271217.pdf [Accessed 30 October 2019], 62 pages.

Anon. 2019. Regulation (EU) 2019/1009 of the European parliament and of the council of 5 June 2019. Available online: https://eur-lex.europa. eu/legal-content/EN/TXT/PDF/?uri=CELEX:32019R1009\&from=EN [Accessed 30 October 2019], 114 pages.

Beyer, D.M. 2003. Basic procedures for Agaricus mushroom growing (CAT UL210 5M8/03ps4599). College of Agricultural Sciences, Agricultural Research and Cooperative Extension, The Pennsylvania State University, College of Agricultural Sciences, University Park, PA 16803, USA. Available online: https:// extension.psu.edu/basic-procedures-for-agaricus-mushroomgrowing [Accessed October 2019], 16 pages.

CEN. 2011. EN 13041:2011. Soil improvers and growing media Determination of physical properties - Dry bulk density, air volume, water volume, shrinkage value and total pore space. CEN, Brussels, Belgium. https://www.cen.eu/.

Curtin, J. and Mullen, G.J. 2007. Physical properties of some intensively cultivated soils of Ireland amended with spent mushroom compost. Land Degradation and Development 18: 355-368.

Fidanza, M.A., Sanford, D.L., Beyer, D.M. and Davis, D.D. 2006. Opportunities for spent mushroom substrate in the lawn and landscape. 2nd International Spent Mushroom Substrate Symposium, Concordville, PA, USA. 17-20 September 2006, Abstract, page 14.

Fidanza, M.A. and Davis, D.D. 2009. Recycled mushroom compost suppresses bird's nest fungi in landscape mulch. Journal of Environmental Horticulture 27: 238-240.

Fidanza, M.A., Sanford, D.L., Beyer, D.M. and Aurentz, D.J. 2010. Analysis of fresh mushroom compost. Horticulture Technology 20: 449-453.

Fleming, R. and MacAlpine, M. 2006. Feasibility of processing spent mushroom substrate to recover additional value. 2nd International
Spent Mushroom Substrate Symposium, Concordville, PA, USA, 17-20 September 2006 (papers), pages 54-67.

Gümüs, I. and Seker, C. 2017. Effects of spent mushroom compost application on the physicochemical properties of a degraded soil. Solid Earth 8: 1153-1116.

Hackett, R. 2015. Spent mushroom compost as a nitrogen source for spring barley. Nutrient Cycling in Agroecosystems 102: 253-263.

Hackett, R., Spink, J., Forristal, D. and Creamer, R. 2010. Impact of management practices on soil organic carbon levels under Irish conditions. National Tillage Conference proceedings 2010, Oak Park, Carlow, Ireland, pages 77-79.

IBM Corp. 2011. IBM SPSS Statistics for Windows, Version 20.0. Armonk, NY: IBM Corp.

Jordan, S.N., Mullen, G.J. and Murphy, M.C. 2008. Composition variability of spent mushroom compost in Ireland. Bioresource Technology 99: 411-418.

Liang, C., Das, K.C. and McClendon, R.W. 2003. The influence of temperature and moisture contents regimes on the aerobic microbial activity of a biosolids composting blend. Bioresource Technology 86: 131-137.

Medina, E., Paredes, C., Pérez-Murcia, M.D., Bustamante, M.A. and Moral, R. 2009. Spent mushroom substrates as component of growing media for germination and growth of horticultural plants. Bioresource Technology 100: 4227-4232.

Medina, E., Paredes, C., Bustamante, M.A., Moral, R. and MorenoCaselles, J. 2012. Relationships between soil physico-chemical, chemical and biological properties in a soil amended with spent mushroom substrate. Geoderma 173-174: 152-161.

Noble, R. and Gaze, R.H. 1994. Controlled environment composting for mushroom cultivation: substrates based on wheat and barley straw and deep litter poultry manure. Journal of Agricultural Science (Cambridge) 123: 71-79.

Noble, R., Dobrovin-Pennington, A., Evered, C.E. and Mead, A. 1999. Properties of peatbased casing soils and their influence on the water relations and growth of the mushroom (Agaricus bisporus). Plant and Soil 207: 1-13.

Phan, C.W. and Sabaratnam, V. 2012. Potential uses of spent mushroom substrate and its associated lignocellulosic enzymes. Applied Microbiology and Biotechnology 96: 863-873.

Regan J.T., Fenton, O. and Healy, M.G. 2012. A review of phosphorus and sediment release from Irish tillage soils, the methods used to quantify losses and the current state of mitigation practice. Biology and Environment: Proceedings of the Royal Irish Academy 112B: $1-27$.

Rinker, D. 2017. Spent mushroom substrate uses: technology and applications. In: "Edible and Medicinal Mushrooms" (eds. D.C. Zied and A. Pardo-Giménez), John Wiley \& Sons Ltd., US, pages 427-454. https://doi.org/10.1002/9781119149446.ch20.

Rowell, D.L. 1994. "Soil Science: Methods and Applications". Longman Group Ltd, UK, 327 pages.

Ryu, C., Finney, K., Sharifi, V.N. and Swithenbank, J. 2008. Pelletised fuel production from coal tailings and spent mushroom compost - 
Part II. Economic feasibility based on cost analysis. Fuel Processing Technology 89: 276-283.

Spink, J., Hackett, R., Forristal, D. and Creamer, R. 2010. "Soil Organic Carbon: A review of 'critical' levels and practices to increase levels in tillage land in Ireland". Teagasc, Oak Park, Co. Carlow, Ireland. 28 pages.

Stewart, D.P.C., Cameron, K.C., and Cornforth, I.S. 1998. Effects of spent mushroom substrate on soil chemical conditions and plant growth in an intensive horticultural system: a comparison with inorganic fertiliser. Australian Journal of Soil Research 36: 185-198.

Teagasc. 2017. Soil Index System. Available online: https://www. teagasc.ie/crops/soil--soil-fertility/soil-analysis/soil-index-system/ [Accessed 13 May 2020].

Uzun, I. 2004. Use of spent mushroom compost in sustainable fruit production. Journal of Fruit and Ornamental Plant Research 14: 157-165.

Varian. 1989. "Analytical methods - flame atomic absorption spectrometry". Publication number 85-100009-00. Varian Australia Pty. Ltd., Victoria, Australia.

Velusami, B. 2013. Stored Spent Mushroom Compost - Measurement of Hydrogen Sulphide Emissions and Material Characteristics. PhD thesis, School of Biosystems and Food Engineering, University College Dublin, Belfield, Dublin 4, Ireland.
Velusami, B., Curran, T.P. and Grogan, H.M. 2013. Hydrogen sulfide gas emissions during disturbance and removal of stored spent mushroom compost. Journal of Agricultural Safety and Health 19: 261-275.

Wall, D.P. and Plunkett, M. 2016. "Major and Micro Nutrient Advice for Productive Agricultural Crops". Available online: https://www. teagasc.ie/media/website/publications/2016/soil-fertility-green.pdf [Accessed 30 October 2019], 180 pages.

Walsh, G. 2009. Spent mushroom compost - fertiliser or fuel. 2009 All Ireland Mushroom Conference and Trade Show, Monaghan, Ireland, 21 May 2009, pages 25-29. Available online: https://t-stor. teagasc.ie/handle/11019/1793.

Walsh, G. 2013. "Spent mushroom compost - nutrient content for application to agricultural crops". Teagasc Technology Update. Available online: https://www.teagasc.ie/media/ website/publications/2013/6355_SMC_NutrientContentNPK.pdf [Accessed 30 October 2019], 3 pages.

Westerman, P.W. and Bicudo, J.R. 2005. Management considerations for organic waste use in agriculture. Bioresource Technology 96: 215-221.

White, P.J., Crawford, J.W., Alvarez, M.C.D. and Moreno, R.G. 2014. Soil management for sustainable agriculture. Applied and Environmental Soil Science 2014: 1-2. 


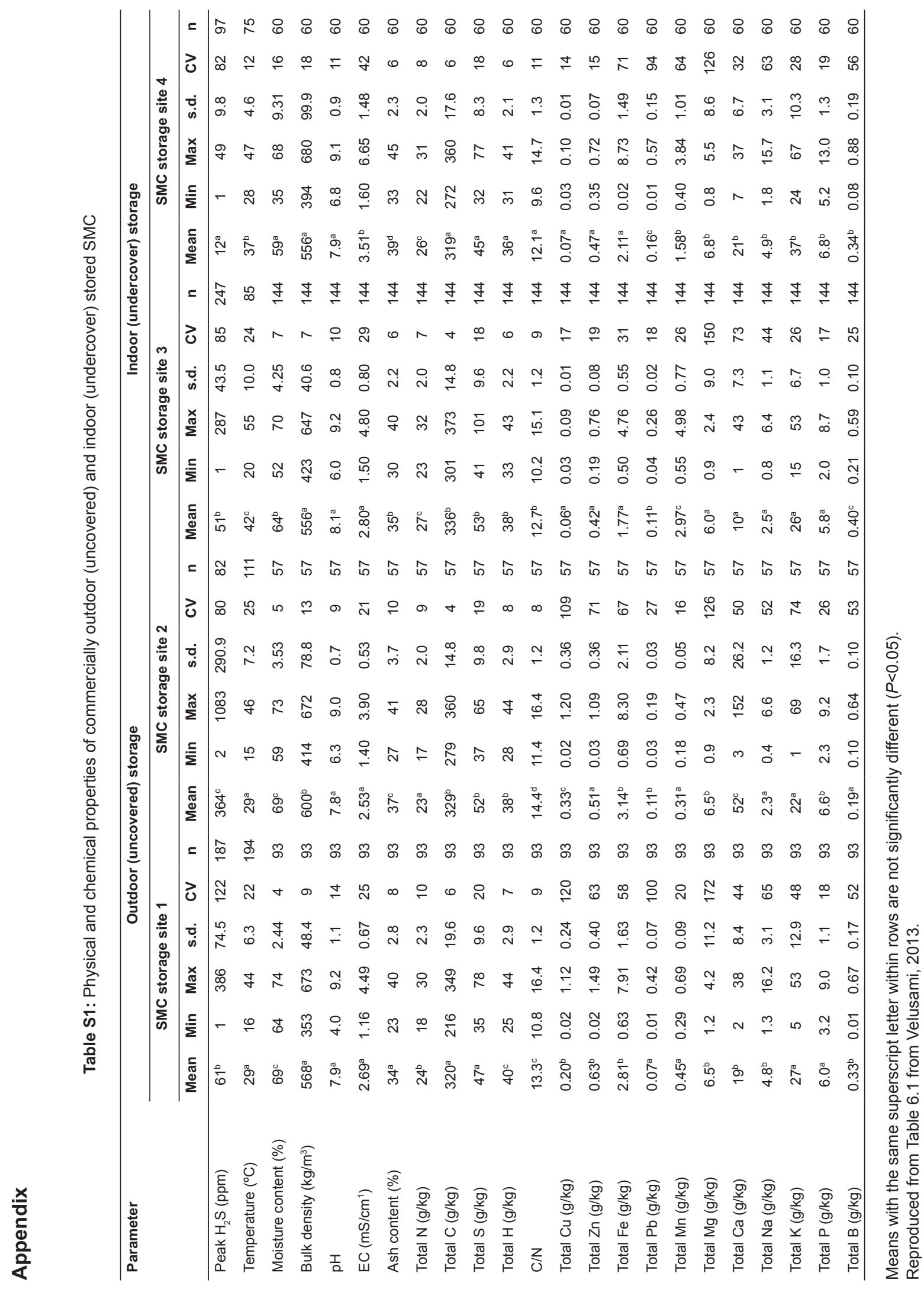

